\title{
Front Matter: Volume 9507
}

, "Front Matter: Volume 9507," Proc. SPIE 9507, Micro-structured and Specialty Optical Fibres IV, 950701 (22 May 2015); doi: 10.1117/12.2197887

SPIE. Event: SPIE Optics + Optoelectronics, 2015, Prague, Czech Republic 


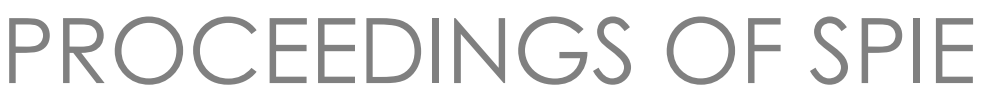

\title{
Micro-structured and Specialty Optical Fibres IV
}

\author{
Kyriacos Kalli \\ Jiri Kanka \\ Alexis Mendez \\ Editors
}

15-16 April 2015

Prague, Czech Republic

Sponsored by

SPIE

Cooperating Organisations

HiPER Project (United Kingdom)

ELI Beamlines (Czech Republic)

Laserlab Europe

Published by

SPIE 
The papers included in this volume were part of the technical conference cited on the cover and title page. Papers were selected and subject to review by the editors and conference program committee. Some conference presentations may not be available for publication. The papers published in these proceedings reflect the work and thoughts of the authors and are published herein as submitted. The publisher is not responsible for the validity of the information or for any outcomes resulting from reliance thereon.

Please use the following format to cite material from this book:

Author(s), "Title of Paper," in Micro-structured and Specialty Optical Fibres IV, edited by

Kyriacos Kalli, Jiri Kanka, Alexis Mendez, Proceedings of SPIE Vol. 9507 (SPIE, Bellingham, WA, 2015) Article CID Number.

ISSN: 0277-786X

ISBN: 9781628416282

Published by

SPIE

P.O. Box 10, Bellingham, Washington 98227-0010 USA

Telephone +1 3606763290 (Pacific Time) · Fax +1 3606471445

SPIE.org

Copyright (@ 2015, Society of Photo-Optical Instrumentation Engineers.

Copying of material in this book for internal or personal use, or for the internal or personal use of specific clients, beyond the fair use provisions granted by the U.S. Copyright Law is authorized by SPIE subject to payment of copying fees. The Transactional Reporting Service base fee for this volume is $\$ 18.00$ per article (or portion thereof), which should be paid directly to the Copyright Clearance Center (CCC), 222 Rosewood Drive, Danvers, MA 01923. Payment may also be made electronically through CCC Online at copyright.com. Other copying for republication, resale, advertising or promotion, or any form of systematic or multiple reproduction of any material in this book is prohibited except with permission in writing from the publisher. The CCC fee code is 0277-786X/15/\$18.00.

Printed in the United States of America.

Publication of record for individual papers is online in the SPIE Digital Library.

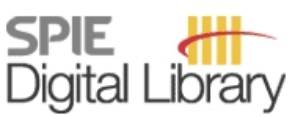

SPIEDigitalLibrary.org

Paper Numbering: Proceedings of SPIE follow an e-First publication model, with papers published first online and then in print. Papers are published as they are submitted and meet publication criteria. A unique citation identifier (CID) number is assigned to each article at the time of the first publication. Utilization of CIDs allows articles to be fully citable as soon as

they are published online, and connects the same identifier to all online, print, and electronic versions of the publication. SPIE uses a six-digit CID article numbering system in which:

- The first four digits correspond to the SPIE volume number.

- The last two digits indicate publication order within the volume using a Base 36 numbering

system employing both numerals and letters. These two-number sets start with 00, 01, 02, 03, 04, $05,06,07,08,09,0 A, 0 B \ldots$. OZ, followed by 10-1Z, 20-2Z, etc.

The CID Number appears on each page of the manuscript. The complete citation is used on the first page, and an abbreviated version on subsequent pages. 


\title{
Contents
}

\author{
$\checkmark$ Authors \\ vii Conference Committee
}

\section{SESSION 1 FIBRES TAILORED FOR APPLICATIONS}

950702 Development of optical fibers for mid-infrared sensing: state of the art and recent achievements (Invited Paper) [9507-1]

950703 Special optical fibers doped with nanocrystalline holmium-yttrium titanates $\left(\mathrm{Ho}_{\mathbf{x}} \mathrm{Y}_{1-\mathrm{x}}\right)_{2} \mathrm{Ti}_{2} \mathrm{O}_{7}$ for fiber-lasers [9507-2]

950704 Spectral broadening in low $\mathrm{OH}$ content and dispersion-managed tellurite fibres for compact mid IR sources [9507-3]

950705 Silica optical fibers with high oxygen excess in the core: a new type of radiation-resistant fiber [9507-4]

950706 Low bending loss square-core optical fiber for optical communication [9507-6]

\section{SESSION 2 MODELLING AND ANALYSIS OF SPECIALITY FIBRE AND COMPONENTS}

950707 Highly nonlinear chalcogenide suspended-core fibers for applications in the mid-infrared (Invited Paper) [9507-7]

950708 Microfluidic flows and heat transfer and their influence upon optical modes in microstructure fibres [9507-8]

950709 Large mode area aperiodic fiber designs for robust singlemode emission under high thermal load [9507-9]

$95070 \mathrm{~A}$ Investigation of optical thin films printed on the surface of facets of photonic crystal fibers [9507-10]

9507 OB Propagation of laser pulse with a few cycles in layered medium with time-dependent dielectric permittivity [9507-11]

\section{SESSION $3 \quad$ SENSORS AND DEVICES BASED ON SPECIALITY FIBRES}

9507 OC Speciality optical fibres for astronomy (Invited Paper) [9507-12]

9507 OE Nanostructured tapered optical fibers for paticle trapping [9507-14] 
9507 OF Specialty fibers for high power lasers and amplifiers (Invited Paper) [9507-15]

SESSION 4 FIBRE DESIGN, PROCESSING AND FABRICATION

9507 OG Soft glass photonic crystal fibres and their applications (Invited Paper) [9507-16]

9507 0l Fabrication of three dimensional microstructure fiber [9507-18]

$95070 \mathrm{~J}$ Investigation of passive and active silica-tin oxide nanostructured optical fibers fabricated by "inverse dip-coating" and "powder in tube" method based on the chemical sol-gel process and laser emission [9507-19]

SESSION 5 POLYMER OPTICAL FIBRE BASED SENSORS AND DEVICES

9507 OK Bragg grating inscription in CYTOP polymer optical fibre using a femtosecond laser [9507-20]

9507 OM Optimisation of polymer optical fibre based interferometric sensors [9507-22]

9507 ON High performance liquid level monitoring system based on polymer fiber Bragg gratings embedded in silicone rubber diaphragms [9507-23]

\section{SESSION 6 TESTING AND CHARACTERISATION METHODS APPLIED TO SPECIAL FIBRE TYPES}

950700 High-precision confocal reflection measurement for two dimensional refractive index mapping of optical fibers (Invited Paper) [9507-24]

9507 OP Characterization of double-clad thulium-doped fiber with increased quantum conversion efficiency [9507-25]

$95070 Q$ Transmission of red-laser radiation by using Bragg fibers with air cores [9507-26]

9507 OR Light-guidance in step-index fibers with non-circular shaped core [9507-27]

POSTER SESSION

9507 OU Nanoimprint lithography using $\mathrm{TiO}_{2}-\mathrm{SiO}_{2}$ ultraviolet curable materials [9507-31]

iv 


\section{Authors}

Numbers in the index correspond to the last two digits of the six-digit citation identifier (CID) article numbering system used in Proceedings of SPIE. The first four digits reflect the volume number. Base 36 numbering is employed for the last two digits and indicates the order of articles within the volume. Numbers start with 00, 01, 02, 03, 04, 05, 06, 07, 08, 09, 0A, OB...0Z, followed by 10-1Z, 20-2Z, etc.

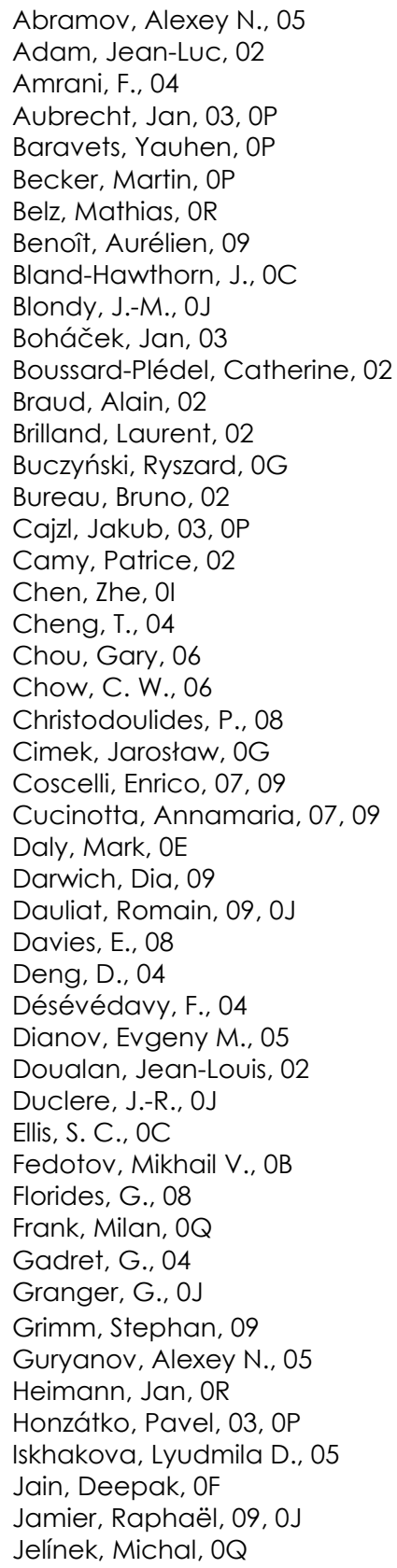

Jules, J. C., 04

Jung, Yongmin, OF

Kalli, Kyriacos, 08, 0K

Kashaykin, Pavel F., 05

Kašík, Ivan, 03, OP, OQ

Kibler, B., 04

Klein, Karl-Friedrich, OR

Klimczak, Mariusz, OG

Komarova, Elena S., OB

Koška, Pavel, OP

Koutsides, C., OK

Kraus, S. OA

Kubeček, Václav, $0 Q$

Kujawa, Ireneusz, OG

Lacraz, A., OK

Latal, J., OA

Lecomte, A., OJ

$\mathrm{Li}$, Jianfeng, 07

Liv, P. F., 06

Lobanov, Nikolay S., 05

Lu, Huihui, Ol

Lucas, Pierre, 02

Lucki, M., OA

Luo, Ying, OI

Ma, Jie, Ol

Marques, Carlos A. F., ON

Matějec, Vlastimil, $O Q$

Mouawad, O., 04

Mrázek, Jan, 03

Nazabal, Virginie, 02

Nic Chormaic, Síle, OE

Nishchev, Konstantin N., 05

Ohishi, Y., 04

Pan, C. L., 06

Pedan, Eugeniy V., OB

Peng, Gang-Ding, ON

Perecar, F., OA

Peterka, Pavel, OP

Picot-Clémente, J., 04

Piechal, Bernard, OG

Podrazký, Ondřej, 03, OP, OQ

Poli, Federica, 07, 09

Polis, M., OK

Pospori, Andreas, OM

Proboštová, Jana, 03

Pysz, Dariusz, OG

Quetel, Lionel, 02

Raisin, Philippe, 00

Raithel, Philipp, OR 
Restoin, C., OJ

Romano, Valerio, 00

Rougier, S., OJ

Roy, Philippe, 09, 0J

Ryser, Manuel, 00

Sahu, Jayanta K., OF

Salgansky, Mikhail Yu., 05

Salin, François, 09

Scheuner, Jonas, 00

Schuster, Kay, 09

Selleri, Stefano, 07, 09

Seyringer, D., OA

Siwicki, Bartłomiej, OG

Smektala, F., 04

Stępień, Ryszard, OG

Stępniewski, Grzegorz, OG

Strutynski, C., 04

Sung, J. Y., 06

Takei, Satoshi, OU

Tariel, Hugues, 02

Theodosiou, A., OK

Tobisch, Tim, OR

Todorov, Filip, OP

Tomashuk, Alexander L., 05

Trofimov, Vyacheslav A., OB

Troles, Johann, 02

Truong, Viet Giang, OE

Webb, David J., OM, ON

Yeh, C. H., 06

Zehetner, J., OA

Zeleny, R., OA

Zhong, Yongchun, 0

Proc. of SPIE Vol. $9507950701-6$ 


\title{
Conference Committee
}

\author{
Symposium Chairs
}

Jiri Homola, Institute of Photonics and Electronics of the ASCR, v.v.i

(Czech Republic)

Chris Edwards, Central Laser Facility, Science and Technology

Facilities Council (United Kingdom)

Mike Dunne, SLAC National Accelerator Laboratory (United States)

and Linac Coherent Light Source (United States)

Ivo Rendina, Istituto per la Microelettronica e Microsistemi, CNR (Italy)

Honorary Symposium Chair

Miroslav Miller, Institute of Photonics and Electronics of the ASCR, v.v.i. (Czech Republic)

Conference Chairs

Kyriacos Kalli, Cyprus University of Technology (Cyprus)

Jiri Kanka, Institute of Photonics and Electronics of the ASCR, v.v.i.

(Czech Republic)

Alexis Mendez, MCH Engineering LLC (United States)

Conference Programme Committee

Jean-Luc Adam, Université de Rennes 1 (France)

John Ballato, Clemson University (United States)

Ole Bang, DTU Fotonik (Denmark)

Hartmut Bartelt, Institut für Photonische Technologien e.V. (Germany)

Aurélien Bergonzo, Fibercore Ltd. (United Kingdom)

Neil G. R. Broderick, The University of Auckland (New Zealand)

Benjamin J. Eggleton, The University of Sydney (Australia)

Christopher Emslie, Fibercore Ltd. (United Kingdom)

Sebastien Fevrier, XLIM Institut de Recherche (France)

Karl-Friedrich Klein, Technische Hochschule Mittelhessen (Germany)

Jonathan C. Knight, University of Bath (United Kingdom)

Michael Komodromos, Frederick University (Cyprus)

Hanne Ludvigsen, Aalto University School of Science and Technology (Finland)

Walter Margulis, Acreo Swedish ICT AB (Sweden)

Saeed Rehman, Fibertronix AB (Sweden)

Valerio Romano, Berner Fachhochschule Technik und Informatik

(Switzerland) 
Kay Schuster, Institut für Photonische Technologien e.V. (Germany)

Waclaw Urbanczyk, Wroclaw University of Technology (Poland)

David J. Webb, Aston University (United Kingdom)

Alexei M. Zheltikov, Lomonosov Moscow State University (Russian

Federation)

\section{Session Chairs}

1 Fibres Tailored for Applications

Kyriacos Kalli, Cyprus University of Technology (Cyprus)

2 Modelling and Analysis of Speciality Fibre and Components

Jiri Kanka, Institute of Photonics and Electronics of the ASCR, v.v.i.

(Czech Republic)

3 Sensors and Devices based on Speciality Fibres

David J. Webb, Aston University (United Kingdom)

4 Fibre Design, Processing and Fabrication

Valerio Romano, Berner Fachhochschule Technik und Informatik

(Switzerland)

5 Polymer Optical Fibre Based Sensors and Devices

Kyriacos Kalli, Cyprus University of Technology (Cyprus)

6 Testing and Characterisation Methods Applied to Special Fibre Types

Kyriacos Kalli, Cyprus University of Technology (Cyprus) 